on schemes of members opting out, or in, under the choices to be given to them in April 1988.

In the paper it is suggested that whilst it is for employers to take decisions on pension scheme design, actuaries have an important role to play in encouraging their clients to review and improve the design of the schemes.

\title{
A LOOK AT EQUITY, BONUSES AND PROFITS USING AN OB PROFITABILITY MODEL
}

\author{
By H. D. White, F.I.A.
}

(Synopsis of a paper presented to the Society on 20 January 1987)

THE paper used modern profitability testing techniques to put a recently maturing with-profit policy under the microscope. The author asked some provocative questions about traditional actuarial practice.

In the first place he demonstrated the need for a high level of equity backing in order to justify current with-profit performance. He then went on to discuss the incidence of equity investment. He demonstrated the pooled interest approach does not give good results as it is distinctly advantageous to invest completely in equities at the commencement of a policy and only move into fixed interests investments closer to maturity. Despite the recent bull market this would have produced maturity values $20 \%$ better than those obtainable under a traditional pooled interest approach. Pooling gives a slow build-up of assets in early years.

Given that most offices now have high equity backing current bonus structures were questioned. The author suggested the nature of the assets justifies a high level of final bonus and a slow build-up of reversionary bonus with a low rate of bonus on sum assured. The paper pointed out that if investment conditions deteriorated existing business and particularly short-term policies would currently be guaranteeing an unjustifiably high level of existing reversionary bonus. This would give rise to inequitable losses and impose restraints on future investment policy and performance.

Other assumptions that affected profitability such as taxation, expenses and surrenders were considered. The most financially important of these were the surrender rates and surrender basis. Historically surrender rates have been lower than at present, but surrender bases were profitable and built up profits for survivors. Due to increased reversionary bonuses current surrender values are now much higher and give cause for concern. These could lead to poor performance and an uncompetitive life insurance industry in the future.

The paper concluded that offices had pursued an appropriate high equity investment policy, but were behind the times with their reversionary bonus policies. Too high levels of reversionary bonuses were giving too generous 
surrender values; reducing our competitive performance by holding back reserves; and were likely to produce serious problems of inequity and even losses if there was a deterioration in the equity market. The current taxation structure of life business was likely to put it in an uncompetitive position compared to other financial competitors for long-term business.

\title{
FINAL PAY PENSION SCHEMES-DEFERRED PAY OR COMPANY PROVIDED BENEFIT?
}

\author{
By A. R. EsColme
}

(Synopsis of a paper presented to the Society on 3 February 1987)

THE paper is concerned solely with funded pension schemes of the final or final average salary type. The following is a brief summary of the arguments and conclusions it contains.

There are two extreme or 'pure' types of final pay scheme, which I call Deferred Pay and Company Benefit Schemes.

Generally, employers (and employees, journalists and politicians) are unaware of the distinctions between the two types of scheme. Consequently many employers with final pay schemes have not considered which type of scheme, or just what compromise between the two, they want to operate.

This gives rise to some confusion of thought and action which in turn causes and has caused conflict with scheme members and their representatives. (The lack of recognition of the two types of scheme may also have given rise to some confusion of thought among accountants, journalists and politicians.)

Actuaries and other pension scheme practitioners would render a service to their corporate clients if they led clients to consider the two types of scheme in their extreme or pure form, the advantages and disadvantages of each and the client's preferences having regard to corporate personnel and financial policies.

In practical terms it might not be possible, or in some instances it might be undesirable, for the client to transform his existing final pay scheme into one or other the two extreme forms. Nevertheless, a consideration of the two types of scheme could well result in clearer objective setting by the employer in relation to this scheme and in particular to the setting of clearer communications objectives, with a resulting reduction in potential misunderstanding and conflict.

The paper contains a number of examples of conflict and confusion of thought which have arisen with final pay schemes. The examples provide a context for the 